\title{
Introduction to the Special Issue on Taika Waititi's Boy
}

Jo Smith and O. Ripeka Mercier

According to popular press, Taika Waititi's feature film Boy (2010) has become the number one New Zealand film of all time. Shot in Waihau Bay with a cast and crew drawn from local communities, Boy is deeply embedded in a local sense of place even as its storyline, narrative themes and mise-en-scene demonstrate a love of global popular culture, particularly pop king Michael Jackson. Boy's success offers an opportunity for scholarly reflection on the current state of representations of te ao Māori, Māori screen production, and the relationship between Māori popular culture, New Zealand national culture and the more global forces that help shape contemporary media.

The genesis of this special issue comes from a one-day symposium, which gathered together a range of academics (students and staff), media industry practitioners and other interested parties who wanted to share and hear things concerning Waititi's 2010 feature film Boy. ${ }^{1}$ There were many voices heard that day and, for a range of reasons, not all have been gathered in this volume. The editors regret these lost voices. As we come to write this introduction we reflect on the richness of that day and how the many different viewpoints of that gathering underscored the complexities and pleasures of watching a feature film that addresses things Māori. The symposium started with participants offering reflections of when, where and under what conditions they first watched Boy. Some viewed the film with whānau and friends in a packed local theatre. Some went to larger film theatres and watched the film with a non-Māori audience. These participants spoke of the discomfort of watching the film among strangers and the ambivalent effects of the audiences' laughter. Some asked: were these people laughing with or at Māori? Other participants spoke of the power of seeing landscapes, waterways and characters both familiar and known and the way that a special sense of community was enabled and affirmed by watching Boy.

\footnotetext{
${ }^{1}$ The symposium was hosted by Victoria University of Wellington. The organisers included Jo Smith (Media Studies); Alice Te Punga Somerville (English); Ocean Mercier (Te Kawa a Māui) and Terese McLeod (Te Kawa a Māui).
} 
This special issue builds on the conversation and ideas generated that day, and offers snapshots of the many ways in which the study of a feature film addressing things Māori might be conducted. Hopefully our special issue offers up a range of voices that are "complicated, internally diverse," and "contradictory" (74). This is Linda Tuhiwai Smith's criteria for Indigenous articulations that might challenge any lingering belief that "Indigenous cultures cannot change, cannot recreate themselves and still claim to be Indigenous", but the criteria is a useful one for also thinking about academic scholarship surrounding things Māori. With the global increase in Indigenous film and media scholarship, one could say that Māori film and media studies is an emerging field of study; one related to an international conversation, but informed by the particularities of places and times specific to New Zealand. These particularities include the ways in which things Māori have helped demarcate and naturalise certain notions of the New Zealand nation.

As many scholars have noted, when ship people encountered shore people in the earliest waves of colonisation, "māori" was the Indigenous term used to signify the norm. How then, as Donna Matahaere has asked, "did Māori, a term intended to denote 'usual' or 'normal' come to define a racial category?" (17). We could answer this question by saying that this structured, regulatory and power-laden category emerged from devastating encounters with settler forms of sociality and the imported norms of Western property law, religion, and gendered, classed and raced relations. Under such conditions it is perhaps easy to see how that which was originally ordinary could come to symbolise all that is deviant, unusual, and uncomfortable. As such, images and articulations of "Māori" have been used as a pliable and mutable resource to differing ends and purposes.

In Decolonizing Methodologies (1999) Linda Tuhiwai Smith argues that anthropological accounts of the warrior-race of New Zealand focused on practices such as the haka and cannibalism to produce a collective colonialist imaginary of Māori as the primitive Other. This process of differentiation functioned to naturalise the colonial project as a morally good and proper mission. Brendan Hokowhitu also calls attention to the use made of images of Māori masculinity when he argues that images of the Māori Battalion in the 1940s emphasized bravery and fortitude at a historical moment when, "the inevitability of coexistence between Māori and Pākehā meant searching for representations of Māori that could be positive and yet non-threatening" $(2003,186)$. Attentive to the expectations 
of a global audience and the ways in which the New Zealand film industry is shaped by these expectations, Leonie Pihama's critique of films such as Once Were Warriors (1994), The Piano (1993) and Rapa Nui (1994) suggests that these films have "contributed to the construction of Māori images globally that have little relationship to our lives" (Dennis and Bieringa, 192). Arguing for films that are "located within historical realities of this land", Pihama implies that the longer histories of Indigenous peoples, places, resources and struggles should form a larger part of New Zealand's cinematic landscapes. In the aftermath of the popularity of Whale Rider (2002), Brendan Hokowhitu continued his earlier critique of the appropriation of things Māori by non-Māori. Construed by some as an "authentic" expression of "Indigenous heritage" (Fox et al, 38), Hokowhitu offers a counterview of Niki Caro's feature film by framing it as a "rehash" of "western clichés" about Indigeneity that function to satisfy a global audience hungry for exotic imagery (2007, 22-24). Concluding that Whale Rider had very little to do with Māori and everything to do with portraying harmonious bicultural fantasies for the sake of a settler nation, Hokowhitu argues that, "Whale Rider continues the western tradition of understanding oneself through the Other" (ibid, 29).

Academic critiques of the use made of images of Mãori chime with the work of creative practitioners. As early as 1975, Patricia Grace made the dynamics of cultural representation the heart of her short story, "Parade". In this story Grace depicts a young woman (Matewai) who has returned to her marae after some years in an urban and Pākehādominated urban environment that has changed her vision of her rural upbringing. Rather than finding comfort and a sense of community in the kapa haka performance included in the annual street parade, Grace's protagonist experiences herself and "other members of my race as others see us" $(1975,84)$. It is this internalised view learnt from her time in the city that causes Matewai to see her whānau and herself as simply members of a "travelling circus, a floating zoo", rather than a community with integrity in its own right (85). Yet, the obligation to "show others who we are" (88), is a function underscored by her elders who encourage her to re-join and continue the performance. By making the inevitabilities of cultural objectification the topic of her creative labours, Grace underscores the difficulties of escaping cultural stereotypes and attendant acts of objectification and appropriation. At the same time, Grace highlights the political and cultural obligations that shadow any Māori 
creative, and her fiction offers up some conceptual solutions that ask her readers to consider their own relationship to things Indigenous. ${ }^{2}$ Other creative practitioners such as Merata Mita and Barry Barclay have continued to examine the double-edged nature of images of Māori, and they have used their films and writings to lay down some important challenges.

Merata Mita's paper, 'The Soul and the Image', addresses the power of cinema and the work of Māori filmmakers to influence and effect social change, and Mita dedicated her life to these ends before her passing in 2010. Named as co-producer of Boy, Mita consistently supported young filmmakers and was a pioneer of Indigenous filmic form. To date, her first fictional feature Mauri (1988) remains one of the most powerful filmic articulations of te ao Māori. As she writes in her paper, Māori filmmakers "have the capacity of Indigenising the screen in any part of the world our films are shown. This represents power and is one reason we make films which are uniquely and distinctly Māori" $(1996,54)$. While a provocation to filmmakers to take up the tools of cinema to re-write a sense of Indigenous belonging, Mita also acknowledged that visual sovereignty onscreen is no easy thing to achieve. While a practitioner might have the power to shape the content of a scene (albeit constrained by the technologies and institutions surrounding the film) there is no way in which the context of viewing can be known and controlled in advance.

In the final sequence of Mauri the spirit of Kara (a kaumatua recently passed) travels to Hawaiki in the form of a heron. Kara's mokopuna, Awatea, races to the hilltop as the camera takes on the viewpoint of the bird, producing aerial views of the land and community below. In these closing moments the land is revealed as a sentient being, and cinematography functions to evoke a landscape in total harmony with its inhabitants (in keeping with a Māori world view). Within a Māori context this understanding needs no commentary or translation. However, Mita recognises the dangers of misrecognition when she notes in an interview with Cushla Parekōwhai:

You have to contend with those sort of really superficial things when you want to shoot the land. All the time it comes up as another pretty landscape or arty shot or selling the scenery

\footnotetext{
${ }^{2}$ Aspects of this discussion of Grace appear in Jo Smith's essay, "Framing Parade", a chapter in Marco Sonzogni's, Covering 'Parade', forthcoming from Waiteata Press.
} 
[...] I tried to keep the signs in nature [...] why should I break with that sort of traditional teaching when I make a film? So it's there in its Māori context and not a Pākehā one. (25)

This comment reiterates the double bind of Indigenous representations addressed in Grace's short story. That is to say, the final sequence of Mauri is either a picturesque marvel in keeping with a tradition of depicting New Zealand landscapes as sublime or it is what Mita intended it to be; a vision from te ao Māori produced from a Māori perspective.

This project, to express a form of Indigenous screen sovereignty, is one that Barry Barclay also struggled long to achieve. In his 2003 talk given in Hawaii titled 'Exploring Fourth Cinema', Barclay announced his intentions to celebrate a category of cinema that, by his own admission, is a nascent one. In a spirit of affirmation Barclay declared, "I don't want to hear about Sites of Resistance any more. Let's talk about Sites of Exuberance". For Barclay, the term 'Fourth Cinema' is a provocation to imagine, and thus to call into being, a cinema made by Indigenous peoples within a nation-state, organised by the principles and laws of a foreign power. Barclay offered up existing films to demonstrate this cinema, including international titles such as Tracey Moffatt's beDevil (1993), Nils Gaup's The Pathfinder (1987), Chris Eyre's Smoke Signals (1998), as well as The Fast Runner (Atanarjuat) by Zacharias Kunuk (2001). New Zealand examples include his own Ngati (1987), and Te Rua (1991) as well as Mita's Mauri, Tamahori's Once Were Warriors (1994) and Don Selwyn's Te Tangata Whai Rawa o Weneti: The Merchant of Venice (2002).

Barclay did not include Whale Rider in this list and the editors wonder (along with Misha Kavka and Stephen Turner in this volume) what Barclay would have made of Waititi's Boy? One could certainly say that Waititi's work to date has demonstrated the boyish "exuberance" that Barclay thought very necessary to fuelling Fourth Cinema. Yet, we would suggest that the spirit underpinning Barclay's concept of Fourth Cinema would probe and examine Boy's conditions of production and reception before adding it to the list of Fourth Cinema examples. This probing would reveal that there is a certain cultural weight behind Boy; suggesting that the film holds true to the dynamic forces of Indigenous cultural production. Merata Mita, Cliff Curtis and Ainsley Gardiner form part of the collective that made Boy possible, and Waititi's and Gardiner's whakapapa connections to Te Whānau a Apanui imbued the production with a necessary sense of located-ness and relationship to 
community that Barclay saw as a dimension of Fourth Cinema. To include Boy as part of Fourth Cinema would mean to engage with the ways in which these networks of relations help shape and inform the final story, the many meanings accrued to the film and its subsequent impact on communities.

When Barclay named the category 'Fourth Cinema' he intended that this concept would infuse all aspects of film culture: from the initial idea of a film, to its conditions of production and reception as well as the filmic language involved. In keeping with the spirit of Barclay's work we would argue that any invocation of the concept of Fourth Cinema has implications for the critical reception of a film as much as the film itself. In New Zealand Cinema: Interpreting the Past, Alistair Fox, Barry Keith Grant and Hilary Radner suggest that Waititi's Boy "reactivates" the tradition of Fourth Cinema that involves "exploring Māori life from a Māori perspective" (38). The editors go on to offer a way of reading Boy that links it to Fourth Cinema practices of the past. They argue:

With its revelation of the destructive consequences for children of negligence on the part of the parents, Boy, in its own gentle way, delivers an indictment as powerful as that launched earlier with respect to urban Māori in Lee Tamahori's Once Were Warriors. (38)

While the timing of the film's release prevented the editors of New Zealand Cinema from providing a more extensive analysis of Boy, the link made between Boy and Once Were Warriors is based on the idea that each film provides an "anatomy of social forces that produce dysfunction in Māori families" (ibid). Yet, the editors only mention a shared theme of parental negligence in both films, without historicising and contextualising the prevalence of this theme in media depictions of things Māori. We are interested in providing a toolbox (methodological, theoretical and otherwise) for thinking about how films such as Boy or even Once Were Warriors might come to matter, and make meaning, in a range of ways. This special issue offers a broad context for reflecting on the significance and contribution that Boy makes to the field of film and media studies.

The status of Waititi as "Māori filmmaker" is one that he deftly negotiates and it is not the purpose of this special issue to adjudicate on what makes a Māori film Māori. As Barclay has argued, that question is "adolescent" and as Matahaere reminds us, the term "Māori" is an eternally compromised one. Rather, our intention here is to provide a space 
where a range of different voices and viewpoints might be heard in relation to a single media event. The purpose behind the emphasis on contradiction is to broaden the available vocabulary surrounding Māori media and Māori creative practices and to spark debate about the many meanings accrued to New Zealand feature films, particularly those films involving te ao Māori. This is the imperative behind this current issue: to instigate incremental shifts in understanding what Māori film and media studies might look like when "Māori" is a term that is continuously unpacked.

Our initial intention for this issue was to expand the scope of academic writing about film and include different ways of talking about moving images, popular culture, te ao Māori and the nation. We also wanted to capture the spirit of debate, exchange and difference that was so much a part of the initial Boy Symposium at Victoria University of Wellington. To this end we have structured the special issue in two parts. We have articles arising from the original Symposium presentations that offer a reading of the film, its conditions of production, commentaries from its DVD version as well as aspects of the film's critical reception and the historical period invoked in the film. These articles include the voices of established academics from a range of disciplines, an undergraduate student and a media practitioner. Once these articles were reviewed and reworked, we made them available to a careful selection of people who have been important to the development of Māori media studies as well as academics who work on Indigenous media from other international contexts. These academics wrote commentaries on the film and the other articles in this issue from their perspectives. The impulse here was to air and circulate the sense of a wider debate about, not only the significance of Boy to New Zealand media culture, but more implicitly, how one might think about what Indigenous or Māori Media Studies might look like. As such, this issue gathers together a rich array of voices all responding to one particular media event. We urge our readers to listen closely to the many different perspectives included in this issue.

In keeping with the intention of expanding existing understandings of film from te ao Māori, the issue begins with a broad overview of Boy's impact and Waititi's career by a fellow creative practitioner, the playwright and fiction writer David Geary. The style of Geary's contribution, 'Taika Waititi: Boy Wonder!' ranges from personal reflections on Waititi's career as a creative practitioner as well as Waititi's media(ted) persona, box office 
statistics and promotional strategies. We think this piece encapsulates much of the ethos surrounding the film and filmmaker. Like a faint echo of the knowing logic of Boy's Bollywood-like end credit sequence, Geary's prose suggests a certain tongue-in-cheek approach to the expectations surrounding Waititi's creative efforts that resonate with the ways in which the practitioner himself negotiates these expectations.

The theme of creativity is continued in Bianca Daniell's article, 'Creative Narratives in Boy', where the author unpacks the importance of storytelling, fantasy and the notion of potential in relation to the three main 'boys' in the film: Boy, Rocky and Alamein. Arguing that each character has a particular imaginative life that helps them to negotiate their worlds and their relationships with one another, Daniell argues that creative imagination is an important aspect of life, but one that risks collapsing into harmful ways of being if used excessively. Creative 'potential' is thus a dual edged concept with positive and negative powers. Daniell describes those scenes that feature fantasy sequences of Michael Jackson, animated pencil drawings by Rocky, as well as the self-deluded nature of Alamein's being in the world. It ends with an analysis of Boy's rather ambiguous conclusion which asks the audience to do the work of imagining the possible futures for this whānau.

At a certain point in his article, Geary argues that the character of Weirdo is one that the film could do without. It is precisely the figure of Weirdo and the way in which the film works its audience (at times, through humour) that Misha Kavka and Stephen Turner focus on in their contribution to this volume. In 'Boy and the Postcolonial Taniwha', Kavka and Turner offer an uncomfortable, and thus powerful, critique. What if the pleasures gained by watching Boy come at some cost? Their article works a critical seam established in the writings of Barry Barclay. Barclay's concept of talking in/talking out offers a model of film analysis that affirms a need for audio-visual sovereignty in the wake of the semiotic excesses of film and television. Talking in/talking out also chimes with Merata Mita's concern over how to "Indigenise the screen", given the disjunctive relationship between film content and viewing context. In this volume, Kavka and Turner tease out the implications of these vexed relations.

According to these authors, Weirdo may seem marginal to the film narrative; however, within the larger socio-political context (informed by the perpetually present 
residues of settler colonialism), Weirdo is key. Noting how the film presents an inner story and an outer story, the authors describe Ocean Ripeka Mercier's kaupapa Māori analysis of Boy as an example of how the film might "talk in" to a Māori audience. Yet Kavka and Turner also demonstrate how the film "talks out" to a non-Māori audience in ways that dehistoricise and naturalise the signs of social deprivation so sharply depicted in the film (this is also Pihama's critique of Once Were Warriors). For these authors, the final sequence of the film (where Michael Jackson meets the Pātea Māori Club), continues the logic of "constitutive forgetting" involving strategies of misdirection that the filmic trope of Weirdo instigates.

In 'Alamein's Encore: Entertainment, Information, Intimacy and Reflection in the Boy DVD Director's Commentary', Ocean Ripeka Mercier makes a contribution to an emerging field of film and media studies; the analysis of ancillary media texts. Noting that the DVD special features include a commentary from Waititi, the director, and Alamein, Waititi's film character, Mercier unpacks the productive dimensions of such an approach to DVD commentaries. As the first scholar to offer an analysis of Boy drawing on a kaupapa Māori framework, in this contribution Mercier extends her research on ancillary media first established in a project concerning the national V48 Hour Furious Filmmaking festival competition. The analysis offered in this special issue helps to flesh out Waititi's creative endeavours and multiple personalities as mediated through these commentaries. In addition, the commentaries allow the pleasure of the feature film to be extended and enriched. Mercier suggests that these commentaries also help to unravel the complexities of the Alamein persona. In doing so, the DVD commentaries provide another opportunity for Waititi to expand the available discourses for understanding and articulating Māori masculinities.

Where earlier articles provide a close analysis of the film, its conditions of reception as well as its ancillary modes of distribution, Jo Smith's article, 'Shaking the Frame: Taika Waititi's Anti-Anthropological Edge', focuses on an aspect of the critical reception of Boy as well as its end sequence which, she argues, provides evidence of an alternate politics of place: one drawn from the productive commingling of local and global cultural forces. Starting with a much-cited international film review of Boy, which bemoaned the film's lack of an "arthouse-ready anthropological edge", Smith turns this criticism into an examination 
of the global expectations attending any expression of Indigenous creativity. Looking across Waititi's film career, as well as the ways in which Waititi has talked about his labours in the popular press, the article locates a consistent theme of trafficking between the universal and the particular in Waititi's work. Smith also argues for an expanded academic vocabulary for understanding the critical and creative dimensions of Indigenous media practices.

April K. Henderson's contribution to this issue, 'Maori Boys, Michael Jackson Dance Moves and that 1984 Structure of Feeling', considers the question of what it was like to be young and Māori in New Zealand in the 1980s by reflecting on four instances of Māori boys on film-both still and moving-and tracing relationships between these mediated moments and the contexts that gave rise to them. If Boy's historical setting invites its audience to reconsider 1984 from the situated vantage point of a pre-adolescent Māori boy on the rural East Coast of New Zealand, Henderson's contribution provides a rich reflection on the wider socio-cultural forces at play at the time. The first media example is a striking black and white 1981 image from an esteemed New Zealand-based photographer; a photo of direct relevance to the political ferment of that year (particularly the Springbok tour), and one that provides a kind of pre-history of the images that follow. The second media example is a 1984 photograph lifted from the pages of a book on New Zealand youth culture which documents the impact of US street dance in this country at a time when New Zealand media was predominately monocultural. The third media text considered is the exuberant 1984 music video Poi E, an iconic New Zealand recording. Henderson argues that it is largely through this video that popular memory of the activities depicted in the second photo is sustained. Drawing these media moments together, Henderson's analysis offers a historicisation of that "1984 structure of feeling" invoked in Waititi's Boy, which invites audiences to understand the broader context of the popular cultural materials being worked through in this feature film.

To conclude the special issue, the editors invited a range of scholars to provide comments on the special issue or on the film itself. Designed to inspire debate, our collection of voices are intended to provoke new research areas on Māori film and media, Indigenous film and media and more generally on New Zealand film and media scholarship. As part of this commentary section, Leonie Pihama offers reflections from her initial viewing of the film as well as comments on aspects of the special issue. At base, Pihama's 
commentary argues for a deeper contextualisation of images concerning Māori, which involves a significant reworking of the grounding principles of media studies and assumptions surrounding New Zealand popular culture.

Taking a more internationally situated perspective, Sergio Huarcaya (native to Lima, Peru) reflects on Boy, drawing on his expertise in the fields of Anthropology and History. Huarcaya argues that Boy deftly negotiates forces of Orientalism and strategic essentialism. Orientalism refers to a process that seeks to define differences (in this case, Indigenous differences) in relation to a normative Western subject. The concept of strategic essentialism derives from Gayatri Spivak's project to rethink social power in relation to prevailing conditions. Where others argue that Boy reinscribes negative stereotypes of Māori masculinities, Huarcaya argues that Waititi's film successfully overcomes the limits of both Orientalism and strategic essentialism.

Arifani Moyo is a PhD candidate whose dissertation explores the theatrical politics and aesthetics of Indigeneity in post-apartheid South Africa. Moyo's commentary addresses the difficulties faced by young boys growing up without role models. He discusses Alamein's rituals of initiation for Boy as an improvised experiment in coming-of-age for both of them, noting that the threat to Boy's natural intuition about growing up is dramaturgically mediated by the comedic image and behaviours of the body of Waititi as Alamein.

Brendan Hokowhitu's commentary reflects on the ways in which reading the articles in this special issue help to clarify an initial sense of "dissociation" from Waititi and his film. Growing up at a similar time to the events that the film depicts, Hokowhitu weaves together personal reflections with more theoretically inflected materials and his contribution greatly compliments the "1984 structure of feeling" addressed in April Henderson's article. Focusing, in particular, on the forms of masculinity invoked in Boy, Hokowhitu's commentary compellingly demonstrates how the assertion of the Indigenous body, or what Hokowhitu refers to as 'embodied sovereignty', is a concept that needs to be taken seriously in both Indigenous critical theory and the study of Fourth Media.

There is much that this special issue on Boy does not do. It does not address the perpetual "boy-ish"-ness of Waititi's body of work overall, nor does it track the range of strong female figures that inhabit Waititi's films, albeit on the periphery. Who can forget 
Rachel House's standout performance in Boy or the range of looks that Moerangi Tihore (as Dynasty) throws Boy as events unfold? Questions yet to be asked concern the relationship between Boy and earlier Māori films such as Strength of Water (2009), Ngāti and Mauri. How might emerging filmmakers take up the lessons of Curtis, Gardiner, Waititi and others? And how might New Zealand's national imaginary reassert its settler-centrism in the face of increasing film and media content from te ao Māori? We invite our readers to explore these questions with us here and to ask further questions of contemporary Māori media practices and the scholarship surrounding these practices.

\section{ACKNOWLEDGMENTS}

Ngā mihi nunui ki te kāhui nā rātou ngā whakaaro i horahora nei. We thank all contributors to the symposium and to this volume. We also thank several anonymous referees for their enriching and timely reviews of articles in this issue. We are very grateful to Elizabeth Kerekere for her assistance with this issue. Financial support for this issue was supplied by Victoria University of Wellington's School of English, Film, Theatre and Media Studies, Te Kawa a Māui, the Pro-Vice Chancellor (Māori) and by MANU-Ao (the Māori Academic Network of Universities across Aotearoa).

Jo Smith (Kāi Tahu) is a senior lecturer in the Media Studies programme at Victoria University of Wellington. She researches in the area of postcolonial media theory, Indigenous media and new media studies. She has published work on DVD technologies, postcolonial cultural politics, and the Indigenous broadcaster, Maori Television.

Ocean Ripeka Mercier (Ngāti Porou) is a lecturer in Te Kawa a Māui (the School of Māori Studies) at Victoria University of Wellington where she explores kaupapa Māori analyses of Taika Waititi's films and leads a nationwide enquiry into the V48 Hours Furious Filmmaking competition.

\section{WORKS CITED}

Barclay, Barry. 'Exploring Fourth Cinema: A Talk Given in Hawaii as Part of Summer School Lectures'. Re-imagining Indigenous Cultures: the Pacific Islands, for the National Endowment for the Humanities, Summer Institute (July 2003): 23. Presentation.

Fox, Alistair, Barry Keith Grant and Hilary Radner. New Zealand Cinema: Interpreting the Past. Bristol and Chicago: Intellect, 2011. Print. 
Grace, Patricia. Waiariki. Auckland: Longman Paul, 1975. Print.

Hokowhitu, Brendan. 'Maori Masculinity, Post-structuralism, and the Emerging Self'. New Zealand Sociology 18.2 (2003): 179-201. Web.

---.'Understanding Whangara: Whale Rider as Simulacrum'. New Zealand Journal of Media Studies 10. 2 (2007): 22-30. Web.

Matahaere, Donna 'Māori, the "eternally compromised noun": Complicity, Contradictions and Post-colonial Identities in the Age of Biculturalism'. Women's Studies Journal 11.1 (1995): 15-24. Web.

Mita, Merata. 'The Soul and the Image'. Film in Aotearoa New Zealand. Eds. Jonathan Dennis and Jan Bieringa. Wellington: Victoria University Press, 1992. 36-54. Print.

Parekowhai, Cushla. 'Korero ki taku Tuakana: Merata Mita and Me'. Illusions 9 (1988): 25. Web.

Pihama, Leonie. 'Are Films Dangerous? A Māori Woman's Perspective on The Piano'. Hecate 20.2 (October 1994): 239-242. Web.

---. 'Repositioning Māori Representations: Contextualising Once Were Warriors'. Film in Aotearoa New Zealand. Eds. Jonathan Dennis and Jan Bieringa. Wellington: Victoria University Press, 1992. 191-194. Print.

Tuhiwai-Smith, Linda. Decolonizing Methodologies. London and New York: Zed Books, 1999. Print. 